\title{
Exploring Women's Migration from Ukraine to Other Countries from the end of the 1980s to the 2020s
}

\section{| Oksana Koshulko |}

Master of Arts in Economy and
Society from Lancaster
University,
Ph.D. in Economic Sciences,
Korsun-Shevchenkivskyi
Pedagogical Professional
College, Korsun-Shevchenkivskyi oksanakoshulko2015@gmail.com

\begin{abstract}
The paper presents the results of research concerning women's migration from Ukraine from the end of the 1980s to the 2020s. The paper considers two types of female migration, based on different motives, reasons, outcomes, and means to achieve the realization of their migration plans. The methodology of the paper consists of primary and secondary sources of information. The two types of female migration explored are those taking place in the 1980 s and those in the 2020s. The first wave of female migration from Ukraine, from the end of the 1980s to 2000, has been called 'women attempting to migrate through despair' and the second wave, from 2000 to 2020, has been called 'attempts by women to migrate due to need and danger'.

KEYWORDS

Women's migration, Ukraine, former USSR, the Iron Curtain
\end{abstract}

\section{INTRODUCTION}

From the end of the 1980s to the 2020s, female migration from Ukraine consisted of various types and has usually been studied in scientific literature through the prism of the fall of the Iron Curtain, the collapse of the USSR and the end of the Cold War. This migration had different motives, reasons, outcomes, and means of realization. In the author's opinion, from the end of the 1980s until the 2000s, women's efforts to leave Ukraine can be called 'women attempting to migrate through despair' and migration from the start of the 21 st century until the 2020s can be called 'attempts by women to migrate due to need and danger'. These are what this paper has explored.

\section{PREVIOUS RESEARCH ON THIS TOPIC}

According to A.R. Morrison, M. Schiff, and M. Sjoblom, 'women now account for nearly half of all international migration'(Morrison, A.R et al. 2007), and so female migration from Ukraine is intertwined with the worldwide migration of women.

Researchers from many countries have studied the phenomenon of female migration from Ukraine through different prisms, looking at motives, reasons, outcomes, and means of realization of the women's migration plans. In their publications, they explored female migration from Ukraine as a country of the former USSR, Eastern Europe, ENP, from behind the Iron Curtain as well as a country that ended the Cold War together with others, etc.

Thus, S. Metz-Göckel, M. Morokvasic, and A.S. Münst explored migration and mobility of women from Ukraine through the prism of an 'Enlarged Europe'(Sigrid Metz-Gockel et al. 2008). H. Pilkington called Ukraine 'the former Soviet Union' (Hilary Pilkington. 1997). $\mathrm{S}$. Marchetti and R. Salih called it 'the geographical area concerned by the European Neighbourhood Policy (ENP)' Marchetti, S., \& Salih, R. 2017), and some of them, T. Dragostinova, explored the migration of women 'across the Iron Curtain'. In this context, they studied the differences between men's and women's migration experiences (Dragostinova, T. 2016). 


\section{Methods of research}

The methodology of the paper consisted of primary and secondary sources of information. The primary sources were case studies conducted in Warsaw, Cracow, Prague, Istanbul, Antalya, and Izmir, among Ukrainian female immigrants, during several scientific international projects in 2014-2019. The secondary sources consisted of books, sites and media information concerning women's migration from Ukraine.

\section{Examination of the types of women's migration 22}

In the paper, two types of female migration from the end of the 1980 s to the 2020 s have been explored.

The first type of female migration from Ukraine from the end of the 1980s to the 2000s is called 'attempt to migrate through despair'.

The second type of migration from 2000 to the 2020 s is called 'attempt to migrate through need and danger'.

Both of these are explored below.

\section{The first type of female migration from Ukraine from the fall of the Iron Curtain to 2000}

In 1979, before the fall of the Iron Curtain, one woman left the country by swimming from a Soviet ship to the coast of Sydney (Edwards, L. 2010). What motives and ambitions forced her to risk so much? Firstly, the desire for liberty from the Soviet Union dictatorship, and secondly, her wish to live in a free world outside of the USSR. Without a doubt, she made her dramatic swim for freedom driven by these wishes and motives (Edwards, L. 2010).

When the Iron Curtain fell and the Cold War finished, women left the country in other ways, the majority of them doing so illegally (Koshulko, O. 2019).

From the case studies, conducted in Turkey, it is possible to say that many women left Ukraine from ships, from Odesa to Istanbul. They were then working as prostitutes [9] or domestic workers in Turkey as they had no legal right to stay or work there. Later many of these women married there as it was almost the only way for them to stay legally in Turkey.

In cases of female migration to Europe, the majority faced the same challenges as their sisters had faced in Turkey, as well as various kinds of discrimination (Piper, N., \& French, A. 2011), abuse, violence, and racism. Unlike those going to Turkey, the women traveled to European countries by cars, trains, foot, and buses. Nevertheless, some female immigrants arrived in European countries by undergoing traumatic and illegal journeys. The case studies in Warsaw and Prague revealed some of the following as illegal means used to travel to Europe: inside coffins or refrigerators, between the wheels of trains or by using the underground mine tunnels that had been excavated under borders (for example, between Ukraine and Slovakia).

It is for these reasons that we call women's efforts to leave Ukraine from the end of the 1980 s to the 2000s 'attempt to migrate through despair,' but what does this mean?

Firstly, it means that women living in Ukraine at the end of the 1980s to the 2000s lacked human rights, women's rights, freedom, truth, the right to freedom of thought and all other forms of liberty. They sought these rights abroad through migration.

Secondly, the women concerned suffered persecution in the former USSR for many reasons, including 'political unreliability', languages, nationalities, sexual orientations, etc.

Thirdly, because the population lacked the most essential goods and food necessary for survival. 
Using the case studies conducted in Turkey, Poland, and the Czech Republic, it is possible to show the motives and reasons that explained the women's attempts to migrate through despair from Ukraine in the period after the fall of the Iron Curtain to 2000 (Figure 1).

The results of women's efforts to leave Ukraine from the end of the 1980s to 2000 were as follows: very often, the women could not return to their country of origin for various reasons. These reasons were political, socio-economic or personal and ruled out any chance of returning to their native country.

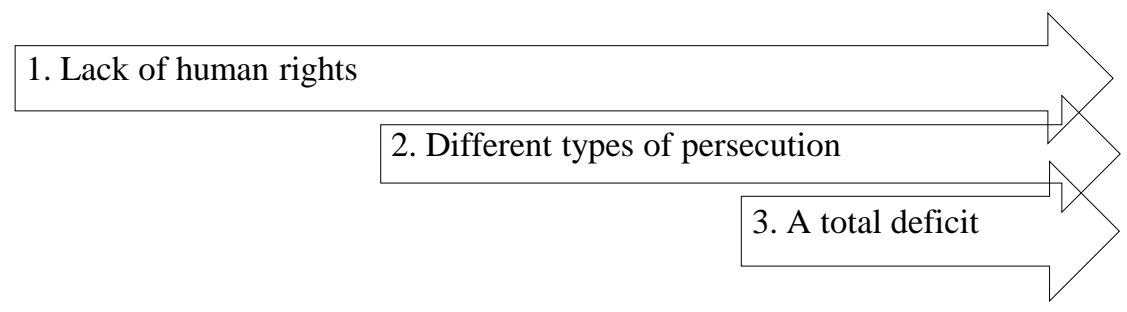

Figure 1. The motives and reasons explaining women's 'attempts to migrate through despair' from Ukraine

\section{The second type of female migration from 2000 to 2020}

From 2000 to 2020, the country enjoyed relative freedom from the past lived under the USSR but the country suffered from poverty in comparison with other countries. For this reason, it is very easy to see why women attempted to migrate other countries, driven by the need of basic commodities.

The case studies conducted in Turkey, Poland, and the Czech Republic show that it is possible to create a scheme of motives and reasons explaining women's attempts to migrate through need from 2000 to 2020, from Ukraine into other countries (Figure 2).

The scheme shows that during the last twenty years female migrants moved from Ukraine to other countries due to:

- lack of job opportunities in Ukraine, low salary, poverty, and unemployment;

- malfunctioning infrastructure and social care, systems of education and health care;

- lack of business development opportunity, reform, and investment in economic and social development and levels of corruption in all spheres of life and activity.

1. Lack of a job in the country of origin, low salary, poverty, unemployment

2. Poor functioning of the infrastructure and social care

3. Lack of opportunities for business development, reforms

Figure 2. The reasons given by female migrants explaining their 'attempts to migrate through need' from Ukraine to other countries

For these and other reasons women sought to migrate from Ukraine to other countries from 2000 to 2020 mainly through need, which is called 'attempts to migrate through need'.

\section{A sub-division of the second type of female migration from 2000 to 2020}

In the second decade of the 21st century, in the years 2014-2015, the regions of Crimea and Donbas within Ukraine were occupied by Russia and the Russian-Ukrainian war started 
in Donbas. This caused a great number of Ukrainians and Crimean Tatars to flee these occupied territories as refugees and externally displaced persons. Data of the United Nations High Commissioner for Refugees (UNHCR) shows, 'one million Ukrainians have sought asylum in neighboring countries' (United Nations High Commissioner for Refugees (UNHCR). 2020).

As a result, migration flows since 2014 from Ukraine to other countries have increased, including female migration.

Unfortunately, in 2014-2015 not all the receiving countries recognized Ukrainians and Crimean Tatars as refugees and asylum seekers. Thus, refugees and asylum seekers from Ukraine were regarded as labor and intellectual migrants.

In these circumstances, the second wave of female migration should be called 'attempts by women to migrate due to need and danger' (Figure 3 ).

1. Lack of a job in the country of origin, low salary, poverty, unemployment

2. Poor functioning of the infrastructure and social care

3. Lack of opportunities for business development, reforms

4. Lack of security because of the occupation and war

Figure 3. The reasons that explain why female migrants from Ukraine made 'attempts to migrate due to need and danger'

What risks did women face in the occupied territories of Ukraine? The situation meant that women could be beaten, raped, humiliated, executed, arrested, abducted, robbed and intimidated. These things could happen to any woman at that time because human and women's rights did not exist. It is very easy to understand why thousands of women left the occupied territories of Crimea and Donbas for their health and safety but it is not easy to understand why these women, refugees and asylum seekers, were not recognized as refugees in other countries. For these reasons, women are referred to as 'migrants' (Koshulko, O. 2019).

\section{External and internal factors that stimulated female migration from Ukraine to other countries}

The internal factors causing female migration have already been explored and described. The external factors stimulating migration from Ukraine were (Figure 4): better opportunities for professional and personal development abroad, better incomes abroad, relative gender equality, relative financial independence from men, expansion of women's horizons, and the relative safety for female refugees from Donbas and Crimea.

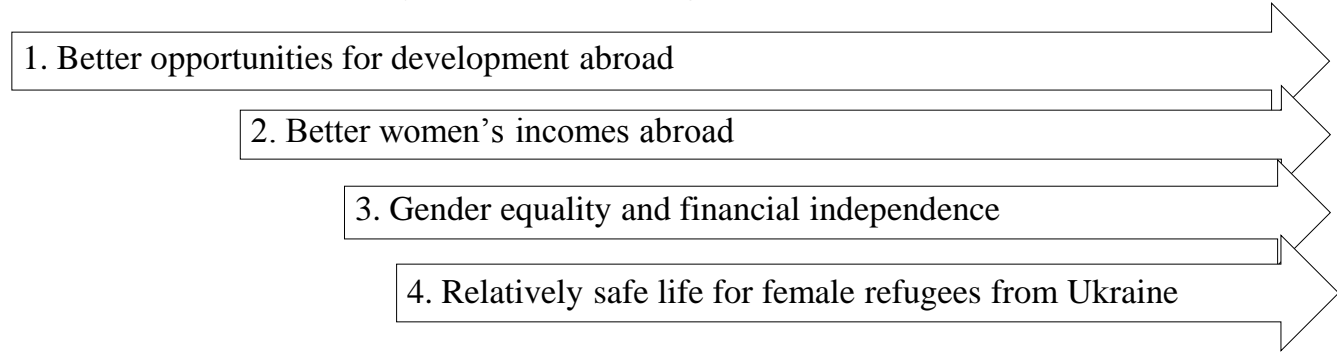

Figure 4. The external factors stimulating female migration from Ukraine

These circumstances contributed to the fact that female migration had every chance 
to develop, as the internal factors did not deter female migration from Ukraine and the external factors stimulated it significantly.

\section{Outcomes of female migration from Ukraine to other countries}

In their new countries, female migrants had to pass through several phases of adaptation. In the opinion of O. Kalervo, these phases were Honeymoon, Crisis, Recovery, and Adjustment (Kalervo, O. 1960).

In addition, female migrants could face discrimination, racism, abuse, and violence in their new countries. The general negative outcomes migration for these women have been described in the paper N. Piper and A. French (Piper, N., \& French, A. 2011):

'...gender-based inequalities, injustice, discrimination, and outright violence continue to permeate all societies to a certain extent, in some form or another. Such outcomes are often brought to the surface through or are the result of, the migrant experience that, for women, typically means dual discrimination based on being female and a non-citizen or absent citizen. Yet migration may allow women to turn these negative outcomes around by gaining greater control of their lives, whether through escape from traditional gender roles, improved knowledge, and awareness about their rights, or newfound financial independence' (Piper, N., \& French, A. 2011).

Therefore, female migrants could face negative outcomes in their new countries regardless of what motives that prompted them to leave Ukraine.

\section{CONCLUSIONS}

The paper is based on several research projects conducted in different countries in recent years. The paper uses the results of case studies conducted among Ukrainian female immigrants in Istanbul, Antalya, Izmir, Warsaw, Cracow, and Prague, and also uses secondary sources of information.

The research conducted shows it is possible to distinguish two types of female migration from Ukraine between the end of the 1980s and the 2020s.

The first type of female migration, from the end of the 1980s to 2000, has been called 'women attempting to migrate through despair'. The reasons for these attempts to migrate during this period have been explored and described in this paper. Among these reasons were lack of human and women's rights, lack of freedom, absence of truth, unavailability of freethinking, absence of liberty, various means of persecution and the absence of essential goods and food.

The second type of female migration, from 2000 to 2020, has been called 'attempts by women to migrate due to need', but later it is renamed 'attempts by women to migrate due to need and danger'. This was brought about by the occupation of Crimea and the occupation and war in Donbas. The second type of female migration considers some of the reasons why these women attempted to migrate. These reasons included, among others, the lack of opportunity for business development, the reforms and investment in economic and social development in the country, the levels of corruption found in all spheres of life and activity in Ukraine, unemployment, low salary, poverty, malfunctioning of the infrastructure, social care, education, and health care systems, absence of security in regions of Ukraine following the occupation and war in the country.

Based on primary and secondary sources of information, the paper explores the negative outcomes for female migrants from Ukraine in their new countries. Among these were dual discrimination, racism, abuse, violence.

The research conducted shows it is possible to conclude that female migration from 
Ukraine will continue because of these external and internal factors. The paper describes the majority of internal factors of both types of female migration from Ukraine, from the end of the 1980s to the 2020s. External factors that stimulated female migration from Ukraine could be the following: better opportunities for women abroad in both professional and private spheres, availability of higher-income abroad, relative gender equality and safety for female refugees, as well as the opportunity to expand horizons and personal development.

\section{ACKNOWLEDGMENT}

The author would like to acknowledge the Scientific \& Technological Research Council of Turkey, the Canadian Institute of Ukrainian Studies of the University of Alberta, the Queen Jadwiga Scholarship Fund of Jagiellonian University, and the Centre for Social Studies of the Polish Academy of Sciences for awards for the author. The awards, research scholarships, and grants allowed implementing the author's international scientific projects on women's migration during 2014-2019.

\section{REFERENCES}

Dragostinova, T. (2016). Refugees or Immigrants? The Migration Crisis in Europe in Historical Perspective. Origins: Current Events in Historical Perspective, 9 (4).

Edwards, L. (2010). Bikini girl who made a splash, The Sydney Morning Herald. https://www.smh.com.au/national/bikini-girl-who-made-a-splash-20091231-ll1h.html

Hilary Pilkington. (1997). 'For the sake of the children': gender and migration in the former Soviet Union. from Post-Soviet Women: From the Baltic to Central Asia, Cambridge University Press, pp. 119-140.

Kalervo, O. (1960). Culture Shock: Adjustment to New Cultural Environments. Practical Anthropology, 7, pp. 177-182.

Koshulko, O. (2019). Exploring Issues of Internally Displaced Persons within Social Policy of Ukraine. Proceedings of the 14th International Conference on Theoretical and Applied Economic Policies 'Economic Growth in Conditions of Globalization: welfare and social inclusion,' National Institute for Economic Research of the Academy of Sciences of Moldova, (II, pp. 196-201), Chisinau, Republic of Moldova.

Koshulko, O. (2019). Field Studies on Female Immigrants in their Host Countries: Challenges and Prospects. MEST Journal, 7 (1), pp. 34-40.

Koshulko, O. (2019). Reasons for the Movement of Female Immigrants to the Republic of Turkey: Research and Analysis. International Letters of Social and Humanistic Sciences, 85, pp. 14-20.

Marchetti, S., \& Salih, R. (2017). Policing gender mobilities: interrogating the 'feminisation of migration' to Europe. International Review of Sociology, 27 (1), pp 6-24.

Morrison, A. R., Schiff, M., \& Sjoblom, M. (2007). The international migration of women. Washington, DC: World Bank.

http://documents.worldbank.org/curated/en/673051468328175051/The-internationalmigration-of-women

Oksana Koshulko (2016). Women from North move to South: Contemporary migration from the Former Soviet Union countries to Turkey, Transnational Press London Ltd.

Piper, N., \& French, A. (2011). Do Women Benefit from Migration? An Editorial Introduction. Diversities, 13 (1), pp. 1-3.

Sigrid Metz-Göckel, Mirjana Morokvasic, \& A. Senganata Münst (2008). Migration and Mobility in an Enlarged Europe: A Gender Perspective, Verlag Barbara Budrich.

United Nations High Commissioner for Refugees (UNHCR). (2020), Ukraine Refugee Crisis https://www.unrefugees.org/emergencies/ukraine/ 